\title{
PREVALENCE OF HELICOBACTER PYLORI INFECTION AMONG CHILDREN WITH PROTEIN -ENERGY MALNUTRITION
}

Azza Ibrahim El-Desouky Pediatric Professor Zagazig University, Sahar Abd El-Raaof ElShaarawy Pediatric Professor Zagazig University, Shimaa Mohamed Safwat Neonatology Resident at Al-Ahrar Teaching Hospital Zagazig (Egypt).

Received: 8 October 2018

Accepted:20 December 2018

Corresponding author

Shimaa Mohamed Safwat shemosafwat@gmail.com

\section{ABSTRACT}

Purpose:The study aimed to assess prevalence of H.pylori infection in children with Protein energy malnutrition (PEM).

Method: The study included 75 infant and young children with malnutrition in a cross section study. We obtain a stool specimens and blood samples from children after consent from the parents, H.pylori antigen in stool, stool analysis and CBC is estimated.

Conclusion: Increased the prevalence of $\mathrm{H}$. pylori infectiona among children with PEM.

\section{INTRODUCTION}

Glo lobally, PEM continues to be a major health burden in developing countries and the most important risk factor for illnesses and death especially among young children ${ }^{[1]}$. The World Health Organization (WHO) estimates that about $60 \%$ of all deaths, occurring among young children aged less than five years in developing countries could be attributed to malnutrition ${ }^{[2]}$. Malnutrition is burden not only on the health systems, but on the entire socio-cultural and economic status of the society. Malnutrition refers to deficiencies, excesses or imbalances in a person's intake of energy and/or nutrients [3].

Helicobacter pylori (H. pylori) is a gram-negative pathogen that is widespread all over the world, infecting more than $50 \%$ of the world's population, with a predominant distribution mainly in developing world countries (up to $80 \%$ ) compared to industrialized ones (20\%$80 \%)^{[4]}$. H. pylori, according to some authors play a role on the balance of nutritional status. The incidence of $\mathrm{H}$. pylori infection in childhood in developing countries is high and has been correlated with malnutrition and growth retardation. Contracting $H$. pylori infection in childhood may result in a series of events that influence morbidity and mortality ${ }^{[4]}$.

\section{PATIENTS AND METHOD}

A cross-section study that was carried on 75 infant and young children with malnutrition diagnosed according to Gomez classification. Weight-for-age used for malnutrition classification as mild (Grade I) fell between $75 \%-89 \%$ of the standard value (standard is the 50th percentile), moderate (Grade II) malnutrition fell between $60 \%-74 \%$, severe (Grade III) malnutrition less than < $60 \%{ }^{[5]}$.

"Gomez classification of malnutrition"

\begin{tabular}{|l|c|}
\hline \multicolumn{1}{|c|}{ Degree of PEM } & $\begin{array}{c}\text { \% of desired body weight for age and } \\
\text { sex }\end{array}$ \\
\hline Normal & $90 \%-100 \%$ \\
\hline Mild: Grade I (1st degree) & $75 \%-89 \%$ \\
\hline Moderate: Grade II (2nd degree) & $60 \%-74 \%$ \\
\hline Severe: Grade III (3rd degree) & $<60 \%$ \\
\hline
\end{tabular}


Inclusion criteria:

- Children with malnutrition aged $>6$ months

- All are full term and their birth weight was normal

Exclusion criteria:

- Infant $<6$ months

- Preterm infants or with intrauterine growth retardation

- Congenital malformation

- Any diseases causing secondary malnutrition like metabolic or CNS diseases

- Chronic renal or hepatic disease

All subjects included in this study were subjected to:

A) Complete history taking

B) Full clinical examination: general examination as vital signs, pallor and edema and full systemic examination including respiratory, cardiovascular, GIT and nervous system to exclude presence of any chronic illness:

Anthropometric measurements particularly:

- Body weight $(\mathrm{kg})$

- Length/height (cm)

- Head circumference $(\mathrm{cm})$

- $\operatorname{BMI}\left(\mathrm{wt} / \mathrm{l}^{2}\right)$

- Weight -for- age (WAZ), height-forage (HAZ), weight-for- height (WHZ) and BMI for-age (BMIZ) were calculated according to $\mathrm{WHO}$ scores.

C) Investigations:-

- Complete blood count

- Stool analysis

- Detection of $\mathrm{H}$.pylori Antigen in stool sample by (immuno chromatography technique): rapid one-step immunoassay for the detection of $\mathrm{H}$. pylori antigens in human stool, utilizes a monoclonal anti-
H. pylori antibody as the capture and detector antibodies. A diluted patient stool sample is dispensed into the sample port of the test device and the appearance of a pink-red line in the reading window next to the letter $\mathrm{T}$ after 5 minutes of incubation at room temperature $\left(20^{\circ}-26^{\circ}\right.$ C) indicates a positive result RESULTS

Children wt ranged from 5 to $10 \mathrm{~kg}$ with mean 7.9, their height ranged from 67 to $93 \mathrm{~cm}$ with mean 80, their head circumference ranged from 42 to $48.6 \mathrm{~cm}$ with mean 46 and BMI from 10.8 to 17.2 with mean 12.6 (Table 2).

Our study showed the prevalence of H.pylori among studied group with malnutrition is $28 \%$ (Table 5). As regard demographic data, our study shows that $48(64 \%)$ of malnourished cases are females and $27(36 \%)$ males, $53.3 \%$ child live in rural and $46.7 \%$ in urban. We found that $33.3 \%$ of malnourished children, their order were the first in their families and $50(66.7 \%)$ were another orders (Table 1$)$.

Our study showed that $85.3 \%$ of malnourished children were low socioeconomic class and $89.3 \%$ live one and more per room and $72 \%$ had anemia (Table 4).

As regard GIT manifestation (Table 3), $86.7 \%$ of malnourished cases complain from diarrhea, $78.7 \%$ cases complain from anorexia and $58.7 \%$ cases complain from vomiting.

Prevalence of H.pylori among mild degree of PEM is $23.8 \%, 32.5 \%$ in moderate and $21.4 \%$ in severe degree. There was a statistically in-significant relation between degree of PEM and $\mathrm{H}$. pylori infection of malnourished cases p $>0.05$ (Table 6). 
Table (1): Demographic data of malnourished cases

\begin{tabular}{|c|c|c|}
\hline \multirow[t]{2}{*}{ Demographic data } & \multicolumn{2}{|c|}{$\begin{array}{l}\text { All studied patients } \\
\qquad(\mathrm{N}=75)\end{array}$} \\
\hline & No. & $\%$ \\
\hline $\begin{array}{l}\text { Sex } \\
\text { Female } \\
\text { Male }\end{array}$ & $\begin{array}{l}64 \\
27\end{array}$ & $\begin{array}{l}48 \\
36\end{array}$ \\
\hline Age (months) & & \\
\hline Mean \pm SD & & $5 \pm 6.4$ \\
\hline Median (Range) & & $7-35)$ \\
\hline $\begin{array}{l}\text { Socioeconomic level } \\
\text { Low } \\
\text { Middle } \\
\end{array}$ & $\begin{array}{l}64 \\
11\end{array}$ & $\begin{array}{l}85.3 \\
14.7\end{array}$ \\
\hline $\begin{array}{l}\text { Residence } \\
\text { Rural } \\
\text { Urban }\end{array}$ & $\begin{array}{l}40 \\
35\end{array}$ & $\begin{array}{l}53.3 \\
46.7\end{array}$ \\
\hline $\begin{array}{l}\text { Crowding index } \\
\text { One and more person live per room } \\
<\text { one person lives per room }\end{array}$ & $\begin{array}{l}67 \\
8\end{array}$ & $\begin{array}{l}89.3 \\
10.7\end{array}$ \\
\hline $\begin{array}{l}\text { Child order within family } \\
\text { First } \\
\text { Others }\end{array}$ & $\begin{array}{l}25 \\
50\end{array}$ & $\begin{array}{l}33.3 \\
66.7\end{array}$ \\
\hline
\end{tabular}

This table shows that $64 \%$ of malnourished cases are females, mean age is 17.45 months old, $53.3 \%$ living in rural areas, $66.7 \%$ their order ar other than the first $89.3 \%$ live one and more per room and $85.3 \%$ are low socioeconomic class.

Table (2): Anthropometric measure for the malnourished cases

\begin{tabular}{|l|c|}
\hline \multicolumn{1}{|c|}{ Anthropometric measure } & $\begin{array}{c}\text { All studied group } \\
\text { (No.=75) }\end{array}$ \\
\hline $\begin{array}{l}\text { Weight (kg) } \\
\text { Mean } \pm \text { SD }\end{array}$ & $7.9 \pm 1.1$ \\
Median (Range) & $8(5-10)$ \\
\hline Length (Cm) & \\
Mean \pm SD & \\
Median(range) & $80 \pm 6$ \\
\hline Head circumference (Cm) & $80(67-93)$ \\
Mean \pm SD & \\
Median (range) & $46 \pm 1.5$ \\
\hline BMI & $46.5(42-48.6)$ \\
Mean \pm SD & $12.6 \pm 1.3$ \\
Median (range) & $12.4(10.8-17.2)$ \\
\hline
\end{tabular}

This table shows the mean weight of malnourished cases is $7.9 \mathrm{~kg}$, mean length is 80 , Head circumference is 46 and BMI is 12.6. 
Table (3): Frequency distribution of GIT upset of malnourished cases

\begin{tabular}{|l|l|l|}
\hline \multirow{2}{*}{\multicolumn{1}{|c|}{ GIT upset }} & \multicolumn{2}{l|}{$\begin{array}{l}\text { All studied } \\
\text { (No.=75) }\end{array}$} \\
\cline { 2 - 3 } & No. & $\%$ \\
\hline Diarrhea & & \\
\cline { 2 - 3 } present & 65 & 86.7 \\
Absent & 10 & 13.3 \\
\hline Anorexia & & \\
present & 59 & 78.7 \\
Absent & 16 & 21.3 \\
\hline Vomiting & & \\
Present & 44 & 58.7 \\
Absent & 31 & 41.3 \\
\hline
\end{tabular}

This table shows that $86.7 \%$ of malnourished cases complain from diarrhea, $78.7 \%$ cases complain from anorexia and $58.7 \%$ cases complain from vomiting.

Table (4): Frequency distribution of anemia of malnourished cases

\begin{tabular}{|l|l|l|}
\hline \multicolumn{2}{c|}{ Anemia } & \multicolumn{2}{l|}{$\begin{array}{l}\text { All studied } \\
(\text { No.=75) }\end{array}$} \\
\cline { 2 - 3 } & No. & $\%$ \\
\hline & & 72 \\
Present & 54 & 28 \\
Absent & 21 & \\
\hline
\end{tabular}

This table shows that $72 \%$ have anemia

Table (5): Prevalence of $H$. pylori among malnourished cases

\begin{tabular}{|c|c|c|}
\hline Helicobacter pylori & \multicolumn{2}{|c|}{$(\mathrm{No}=75)$} \\
\cline { 2 - 3 } & No. & $\%$ \\
\hline Present & 21 & 28 \\
Absent & 54 & 72 \\
\hline
\end{tabular}

This table shows the prevalence of Helicobacter pylori among malnourished cases is $28 \%$ 


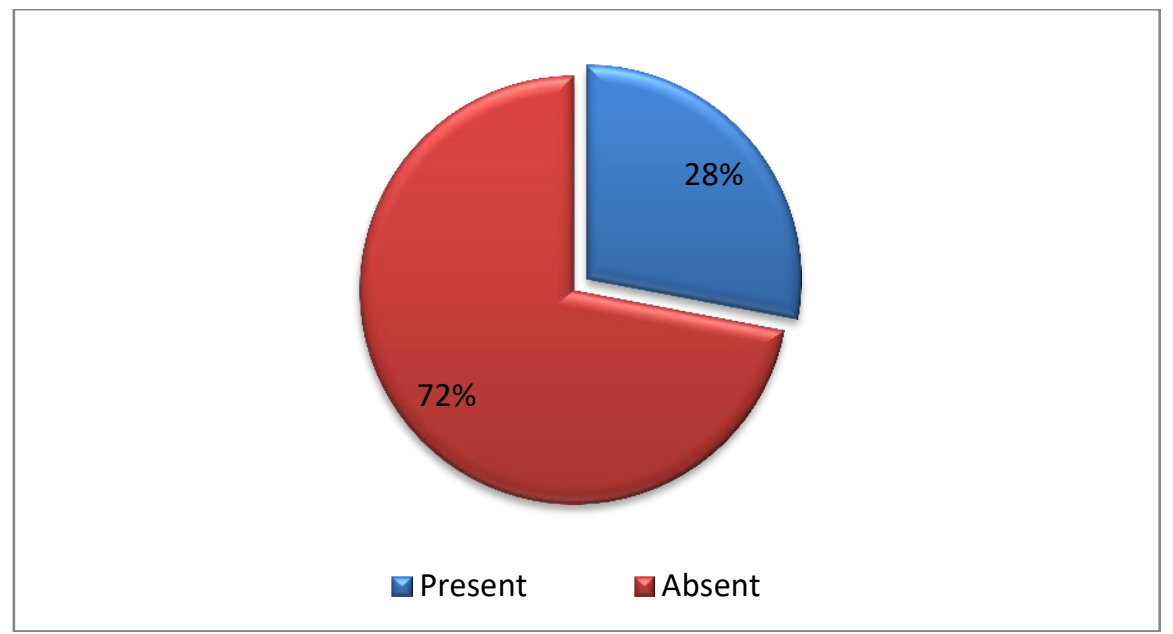

Fig.(1): Percent of H. pylori among malnourished cases

Table (6): Relation between degree of PEM and H.pylori in malnourished cases

\begin{tabular}{|c|c|c|c|c|c|c|c|}
\hline \multicolumn{8}{|c|}{ H. pylori } \\
\hline & \multirow[t]{2}{*}{ Total (n) } & \multicolumn{2}{|c|}{ Present(21) } & \multicolumn{2}{|c|}{ Absent(54) } & \multirow[t]{2}{*}{ Test } & \multirow{2}{*}{$\begin{array}{l}\text { p-value } \\
\text { (Sig.) }\end{array}$} \\
\hline & & No. & $\%$ & No. & $\%$ & & \\
\hline \multicolumn{8}{|c|}{ Degree of PEM } \\
\hline Mild & 21 & 5 & 23.8 & 16 & 76.2 & \multirow{3}{*}{$\begin{array}{l}\mathrm{X}^{2} \\
0.9\end{array}$} & \multirow[t]{3}{*}{$0.6(\mathrm{NS})$} \\
\hline Moderate & 40 & 13 & 32.5 & 27 & 67.5 & & \\
\hline Severe & 14 & 3 & 21.4 & 11 & 78.6 & & \\
\hline
\end{tabular}

This table shows that there is statistically in-significant relation between degree of PEM and H. pylori infection of malnourished cases $\mathrm{p}>0.05$.

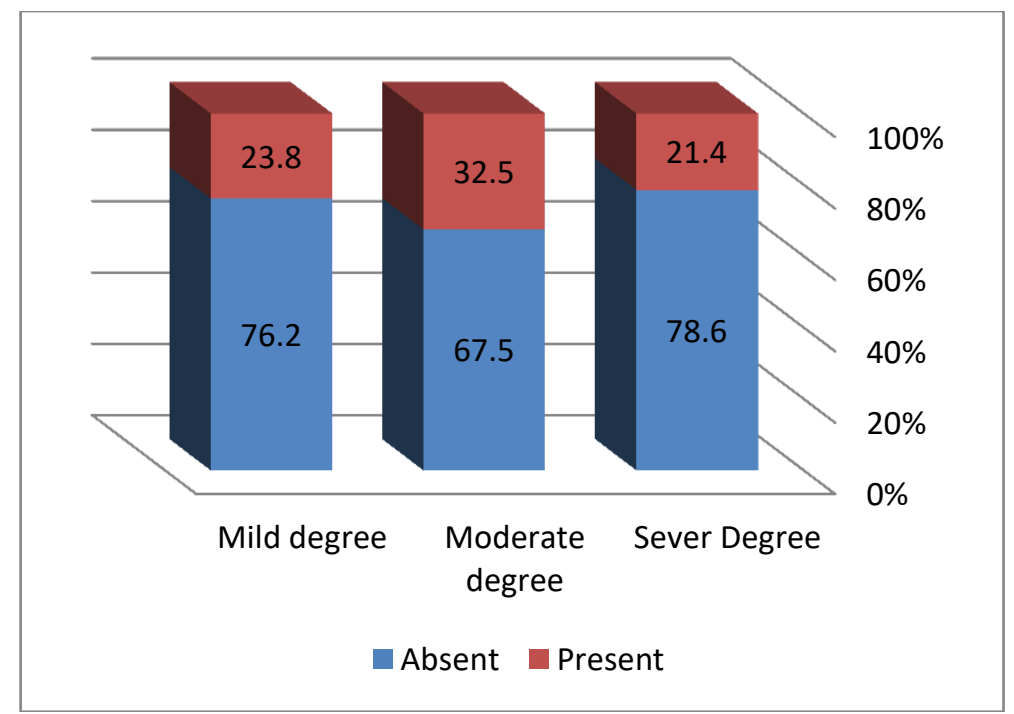

Fig.(2): Percent of $\mathrm{H}$ pylori infection according to degree malnutrition children

\section{DISSCUSSION}

PEM has been identified as the most lethal form of malnutrition which indirectly or directly causing annual death of at least 5 million children worldwide ${ }^{[6]}$.
The incidence of $\mathrm{H}$. pylori infection in childhood in developing countries is high and has been correlated with malnutrition and growth retardation ${ }^{[5]}$ and it seems to be the primary event for 
chronic malnutrition and diarrhea syndrome with failure to thrive ${ }^{[7]}$.

Prevalence of H.pylori among studied group with malnutrition is $28 \%$. A study done by Barakat et al in 2008 found that H.pylori infection had a high prevalence in malnourished children $(66 \%)$ and it may be an important co-factor in the etiology of some aspects of protein energy malnutrition $^{[8]}$. Abdulqawi et al 2012 found in a study on 50 symptomatic Egyptian children whose ages ranged between two and eighteen years with dyspeptic symptoms (recurrent abdominal pain, vomiting, diarrhoea, anorexia, failure to thrive, iron deficiency anaemia) that $68 \%$ of patients were positive for $\mathrm{H}$. pylori test $^{[9]}$.

As regard demographic data, our study shows the prevalence of malnutrition among females 48(64\%) was more than it's prevalence among male children $27(36 \%)$, Dey and Chaudhuri in 2008 in astudy done in West Bengal among under five children found that significantly higher proportion of malnutrition among female children compared to the males ${ }^{[10]}$. On the contrary Ahmed et al in 2012 in his study demonstrated that male were significantly more underweight, stunted and wasted than the female children ${ }^{[11]}$.Abdullah in 2017 found that malnutrition was more prevalent in males than in females ${ }^{[12]}$.

We found that of malnourished children live in rural $(53.3 \%)$ more than urban $(46.7 \%)$ Our results support the findings of prior studies that have also described the urban- rural differences in health in Egypt. People living in urban areas are provided with better access to health services, education and other social support systems which are either not available or not easily accessible to residents in rural areas ${ }^{[13]}$. Sahu et al in a study among under-five children in India found that prevalence of stunting (chronic malnourishment) was higher among rural children $(21.79 \%)$ as compared to urban children $(13.79 \%)^{[14]}$. Herrador et al in 2014 in a cross-sectional study of January 2019 Volume 25 Issue 1 malnutrition showed that prevalence of stunting among school-aged children was $42.7 \%$ in rural areas and $29.2 \%$ in urban areas ${ }^{[15]}$.

We found that $25(33.3 \%)$ of malnourished children, their order were the first in their families and 50(66.7\%) were another orders, Zottarelli et al in multivariate analysis was carried out among children stunting only for births of second and higher orders, the multivariate analysis excluded the first order births ${ }^{[13]}$. On the contrary, Mahmoud et al in 2017 in a study showed that there was no relationship between birth order and stunting ${ }^{[16]}$.

Our study showed association between socioeconomic levels and malnutrition, $85.3 \%$ of malnourished children were low, Mahmoud et al in a study showed a similar trend in the association between educational level and stunting in univariate analysis ${ }^{[16]}$. On the contrary, Rahman et al in 2016 showed that higher education of mother, better household socio-economic conditions and prolonged birth intervals alone are not sufficient in bringing about substantial reductions in prevalence of child malnutrition in Bangladesh ${ }^{[17]}$. .

In our study, $89.3 \%$ of malnourished children live one and more than one person per room. Abdullah in 2017 in a study on nutritional status of children under 5 years in Sheikh-Omar center in Baghdad city found that prevalence of malnutrition has been found to be higher among crowding index of 5 or more person per room ${ }^{[13]}$. On the contrary, Mahmoud et al in 2017 showed that there was no association between stunting and crowding index ${ }^{[16]}$.

Malnutrition may cause and worsen diarrhea and other infections due to a weakened immune system, so diarrhea and malnutrition are known to have a bidirectional relationship, that is, they are potentially causing each other ${ }^{[18]}$. There are several possible explanations for these findings, and they have been described, malnourished children have greater 
susceptibility to infections, especially those infections of the gastrointestinal tract. Conversely, specific enteric infections have been found to cause malnutrition ${ }^{[19]}$.

We found that there was association between diarrhea and malnutrition, $86.7 \%$ of malnourished children had diarrhea. Ferdous et al in 2013 showed direct significant associations between malnutrition and severity of diarrheal diseases, found that $28 \%$ of the children malnourished and whose ages 24-59 months were more susceptible to severe diarrheal disease ${ }^{[19]}$.

We found that there was association between anorexia and malnutrition, $78.7 \%$ of malnourished children had anorexia, Nicholls, et al in 2002 in a study including 172 children (aged 7-16 y) with eating disorders including anorexia receiving specialist treatment, fat mass index (FMI) and fat-free mass index (FFMI) were calculated, both were reduced and associated with malnutrition ${ }^{[20]}$. Assem et al in 2018 found significant difference in stature growth among those with poor appetite with (95.2\%) of patients with poor appetite $^{[21]}$.

We found that there was association between vomiting and malnutrition, $58.7 \%$ of malnourished children had vomiting. Nagata et al showed that vomiting and WAZ at 1 year were significant predictors of undernutrition at 2 years ${ }^{\text {[22] }}$. Although, Sermet-Gaudelus et al in 2000) showed that vomiting was not significant predictors of undernutrition ${ }^{[23]}$.

In 2014 , around $21 \%$ or 2.1 million under-five Egyptian children were stunted, and $9 \%$ weighed too low for their age among 6-59 months old children, 27 per cent suffered from anemia due to iron deficiency ${ }^{[24]}$. With the baseline prevalence of childhood malnutrition and anaemia established, further public health interventions could be implemented specifically to target the burden of anaemia. When the prevalence of anaemia exceeds $30 \%$, the WHO recommends universal iron supplementation for all children aged between 6 and 59 months [25].

Our study showed association between anaemia and malnutrition, $72 \%$ of malnourished children anaemic. Thorne et al in a study among children aged 0-59 months on the Bijagos, West Africa found that 353 out of $440(80.2 \%)$ children were anaemic ${ }^{[26] \text {. }}$

There was statistically insignificant relation between degree of malnutrition and $\mathrm{H}$. pylori infection. Our result is in agreement with Egorov et al in 2010, showed that prevalence rates of Helicobacter infection at study exit were $73 \%$ in substantially malnourished, $47 \%$ in mildly malnourished, and $67 \%$ in normally nourished children [27]. On the contrary, Soylu and Ozturk in 2008 found that malnutrition rate was similar in the $\mathrm{H}$. pylori positive and negative groups ${ }^{[28]}$.

\section{Conclusions}

The prevalence of $\mathrm{H}$. pylori infection among children with PEM is $28 \%$ which is considered high for this age and it may correlate with malnutrition.

\section{REFERENCES}

1. Ubesie AC, Ibeziako NS, Ndiokwelu CI, Uzoka $C M$ and Nwafor $C A$ (2012): Under-five Protein energy malnutrition admitted at the University of in Nigeria Teaching Hospital, Enugu: a 10 year retrospective review.Nutr J, 11(1):43-46.

2. Faruque A $\mathbf{S} \mathbf{G}$, Ahmed A M S, Ahmed T, Islam M M, Hossain M I, Roy S K et al (2008): Nutrition: basis for healthy children and mothers in Bangladesh.J Health Popul Nutr, 26(3): 325-339.

3. WHO (2016): What is malnutrition?. http://www.who.int.

4. Franceschi F, Annalisa T, Teresa D R, Ianiro G, Franco S, Viviana $G$ et al (2014): Role of Helicobacter pylori infection on nutrition and metabolism. WJG, 20(36): 12809-12817.

5. Gomez F, Ramos G, Frenk S, Cravitio $M$, Chavez $R$ and Vazquez J (1956): Mortality in second and third degree malnutrition. J Trop Pediatr, 2(2): 77-83.

6. Akugizibwe R, Kasolo J, Makubuya D $B$ and Damani A M (2013): Missed opportunities in the diagnosis and 
management of protein energy malnutrition among children under 5 years in Waki. J Public Health Epidemiol, 5(11): 463-470.

7. Saboktakin L, Rafeey M, Kousha A and Moradi S M (2012): Study on prevalence of Helicobacterpylori infection in adolescents with failure to thrive to compare with control group. Life Sci J, 9: 1425-31.

8. Barakat S H, Madina E H, El-Neanaey W and Sayed R (2008): Helicobacter pylori infection: Relation to Protein-losing enteropathy in malnutrition, BMJ,93(2): 1-4.

9. Abdulqawi K, El-MahalawayA M, Abdelhameed A and Abdelwahab A A (2012): Correlation of serum antibody titres with invasive methods for rapid detection of Helicobacter pylori infections in symptomatic children. Int J Clin Exp Patho, 93(4): 295-304.

10. Dey I and Chaudhuri $R \quad N$ (2008): Gender inequality in nutritional status among under five children in a village in Hooghly district, West Bengal. Indian J Public Health, 52(4): 218-20

11. Ahmed A M S, Ahmed T, Roy S K, Alam $N$ and Hossain $M$ I (2012): Determinants of under nutrition in children under 2 years of age from Rural Bangladesh. Indian Pediatr, 49(10):821824

12. Abdullah M M (2017): Nutritional status of children under 5 years in Sheikh-Omar center in Baghdad city. Al-Kufa J Biol, 9(3):78-85

13. Zottarelli L K, Sunil T S and Rajaram $S$ (2007): Influence of parental and socioeconomic factors on stunting in children under 5 years in Egypt. UTSA, 13(6):1330-1342.

14. Sahu S K, Kumar S G, Bhat B V, Premarajan K C, Sarkar S, Roy G et al (2015): Malnutrition among under-five children in India and strategies for control. J Nat Sc Biol Med, 6(1): 18-23.

15. Herrador Z, Sordo L, Gadisa E Moreno J, Nieto J, Benito A et al (2014): Crosssectional study of malnutrition and associated factors among school aged children in rural and urban settings of Fogera and Libo Kemkem districts, Ethiopia. PLoS One, 9(9): 105880.
16. Mahmoud A O, Zayed $K M$ and Shawky N A (2017): Stunting among Children Attending a Pediatrics Outpatient Clinic in Cairo, Egypt. EJCM, 35(3):3-42.

17. Rahman M S, Howlader T, Masud M S and Rahman M L (2016): Association of low-birth weight with malnutrition in children under five years in Bangladesh: Do mother's education, socio-economic status, and birth interval matter?. PloS one, 11(6):0157814.

18. Njuguna $J$ and Muruka $C$ (2011): Diarrhoea and malnutrition among children in a Kenyan District: a correlational study. J Rural and Trop Publ Health, 10: 35-38.

19. Ferdous F, Das S K, Ahmed S, Farzana F D, Latham J R, Chisti $M J$ et al (2013): Severity of diarrhea and malnutrition among under five-year-old children in rural Bangladesh. Am J Trop Med Hyg, 89(2):223- 228.

20. Nicholls D, Wells J C, Singhal $A$ and Stanhope R (2002): Body composition in early onset eating disorders. Eur J Clin Nutr, 56(9): 857.-865

21. Assem A A, Raneem A A and Reem M G (2018): Prevalence and Causes of Malnutrition Among Children with Cerebral Palsy in Maternity and Children Hospital, AIMadinahAIMonawarah, KSA. Int J Med Res Prof, 4(1): 48-53.

22. Nagata J M, Gippetti J, Wager $\mathbf{S}$, Chavez $A$ and Wise $P$ H (2016): Prevalence and Predictors of Malnutrition among Guatemalan Children at 2 Years of Age. PloS one, 11(11): 0164772.

23. Sermet-Gaudelus I, Poisson-Salomon A S, Colomb V, Brusset M C, Mosser F, Berrier F and Ricour C (2000): Simple pediatric nutritional risk score to identify children at risk of malnutrition. AJCN, 72(1): 64-70.

24. UNICEF (2014): Egypt demographic and health survey 2014. http:// Unicef.org/Egypt.

25. WHO (2001): Iron deficiency anaemia: assessment, prevention and control: a guide for program managers. http://www.who.int.

26. Thorne C J, Roberts L. M, Edwards D $R$, Haque S, Cumbassa $A$ and Last $A$ R (2013): Anaemia and malnutrition in 
children aged 0-59 months on the Bijagos Archipelago, Guinea-Bissau, West Africa: a cross-sectional, population-based study. Paediatr Int Child Health, 33(3): 151-160.

27. Egorov A I, Sempértegui F, Estrella B, Egas J, Naumova E $\mathbf{N}$ and Griffiths J K (2010): The effect of Helicobacter pylori infection on growth velocity in young children from poor urban communities in Ecuador. International J Infect Dis, 14(9):788-791.

28. Soylu Ö B and Ozturk Y (2008): Helicobacter pylori infection: effect on malnutrition and growth failure in dyspeptic children. Eur J Pediatr. 167(5): 557-562.

How to cite this article: El-Desouky AI, El-Shaarawy SA, Safwat SM. Prevalence of Helicobacter pylori infection among children with protein-energy malnutrition. ZUMJ 2019; 25 (1): 22-30. 